\title{
Corporate Social Responsibility and Job Pursuit Intention of Employees in Vietnam
}

\author{
Linh Viet HOANG ${ }^{1}$, Hieu Minh VU², Vu Minh NGO³
}

Received: September 10, 2020 Revised: November 02, 2020 Accepted: November 05, 2020

\begin{abstract}
As the Industrial Revolution 4.0 is spreading its wings all over the world and, therefore, also in Vietnam, the logistics industry in Vietnam is facing a severe shortage of human resources in both quantitative and qualitative terms. The role of human resources management (HRM) becomes extremely important. Recruitment is considered the first major function of HRM practices and is the cornerstone of successful in business. In order to improve the recruitment strategy, recruiters need to better understand job pursuit intentions (JPI) of job seekers. Therefore, this study investigates how four dimensions of corporate social responsibility (CSR) affect JPI among employees working in the logistics sector in Vietnam. The secondary data are from previous studies and published newspaper articles. Meanwhile, the primary data are collected from consultation with 10 experts and through five in-depth structured interviews with 30 randomly-selected employees as well as 288 survey questionnaires returned from employees in the logistics companies in Vietnam. The findings show that economic citizenship, legal citizenship and ethical citizenship are positively related to JPI of job seekers, where economic citizenship appears to be the most influential factor. The limitations of the study and an agenda for further research are put forward.
\end{abstract}

Keywords: Corporate Social Responsibility (CSR), Employer Attractiveness, Job Pursuit Intention (JPI), Logistics Industry, Recruitment Strategy

JEL Classification Code: M10, I20, I23, Z30

\section{Introduction}

Given the exponential boom of Industrial Revolution 4.0 in Vietnam, the role of logistics technologies have appeared as an increasingly significant tool in the automotive logistics industry. Human resource management (HRM), an essential part of Industrial Revolution 4.0, has a big influence on the process of digital transformation (Bayraktar \& Ataç, 2018). Although the emergence of digital technologies in organizations reduces the dependence on low-skilled

${ }^{1}$ First Author. Graduate School, HELP University, Malaysia.

Email: hoangvietlinh124@gmail.com

${ }^{2}$ Corresponding Author. Faculty of Business Administration, Van Lang University, Ho Chi Minh City, Vietnam [Postal Address: 45 Nguyen Khac Nhu, Co Giang Ward, District 1, Ho Chi Minh City, 700000, Vietnam] Email: hieu.vm@vlu.edu.vn

${ }^{3}$ School of Banking, University of Economics Ho Chi Minh City, Vietnam. Email: ngominhvu@gmail.com

(c) Copyright: The Author(s)

This is an Open Access article distributed under the terms of the Creative Commons Attribution Non-Commercial License (https://creativecommons.org/licenses/by-nc/4.0/) which permits unrestricted non-commercial use, distribution, and reproduction in any medium, provided the original work is properly cited. workers, the demand for high-quality human resources is more critical than ever. Also confirmed by Nguyen and Luu (2020), human resources significantly enhance the capacity and simultaneously increase the competitive advantages of all businesses.

In the context of Vietnam's logistics industry, the workforce has a severe shortage of both quantity and quality (Nguyen, 2020). As per statistics from Vietnam Logistics Association in 2020, there are more than 3,000 firms in the logistics industry (excluding ports, courier, air, sea, land, and shipping companies) (Thu, 2020) and most logistics companies have been experiencing a serious lack of qualified human resources in terms of professional knowledge, skills and English proficiency (Nguyen, 2020). This challenge partly stems from the great gap between the quality of education and the expectations of business organizations in Vietnam (Le et al., 2020). Most employees in this industry have not been properly trained (Linh \& Huong, 2020; Thu, 2020). This indicates that the quality of human resources in the logistics industry is very low (Rodríguez-Espíndola et al., 2018), and human resource management has become vital for all the organizations and especially in the logistics industry. 
Recruitment is one of the most vital components of human resource management as it determines the characteristics of the applicant pool and identifies individuals for potential employment (Turban \& Cable, 2003). A key step in a successful recruitment strategy is how to increase the JPI of job seekers (Williamson et al., 2003). Organizations that can attract more applicants to fill job vacancies within their organization will have more opportunities to recruit the best people for the organization. According to Highhouse et al. (2003), JPI is defined as a candidate's intention to pursue a job at a specific company they perceive as a positive workplace. Based on the signaling theory, corporate social responsibility (CSR) is one of the most influential job attributes in attracting potential candidates by signaling the company's norms, values, business standards, and working conditions (Greening \& Turban, 1996). Much previous research confirms the significant relationship between CSR and JPI of applicants (Chaudhary, 2018; Dawkins et al., 2016; Kumari \& Saini, 2018; Moorthy et al., 2017). Therefore, to maintain competitiveness in recruiting the best employees, organizations should focus more on integrating CSR practices into a recruitment strategy. However, not only many logistics businesses, but also other companies in other industries in Vietnam, fail to use CSR (My, 2000), especially in the recruitment activities, and there is very limited research investigating the significant role of CSR in attracting employees. Also, in terms of the JPI, known as the intentions, behaviors, or decision of potential employees to become a member of a particular organization (Beenen \& Pichler, 2014). The JPI is important to both the organizations and the job seekers (Syaebani et al., 2015). In the literature, many studies investigate the key role of CSR on JPI, but little is known about how CSR and especially how each dimension of CSR affects the JPI of job seekers in the logistics industry in the Vietnamese context. Therefore, this study attempts to fill the gap by modeling CSR and JPI for the successful recruitment of logistics companies. This study seeks to shed a light on the relationship between four dimensions of CSR - economic citizenship, legal citizenship, ethical citizenship, and philanthropic citizenship, and the JPI of job seekers. On the other hand, this study aims to point out the level of interaction effects among variables, and its findings can assist organizations in the more effective development of the recruitment strategy to increase applicant's JPI.

\section{Literature Review}

\subsection{Signaling Theory}

Signaling theory is useful to describe the behavior of the two parties accessing different information. The signaling theory is used in this study to explain the rationales why job seekers are interested in a specific company. The theory claims that, in the early process of searching for a career, job applicants utilize any information they can find to assess a company (Ehrhart \& Ziegert, 2005). This information is considered as signals, driving prospective applicants' judgment about an organization (Celani \& Singh, 2011). Judgments involve organizational goals, values, and possible attitudes of the organization towards society (Greening \& Turban, 2000; Hetze, 2016). Based on the signaling theory, CSR is one of the most significant job attributes that attract job seekers to apply for a job at a specific company. This sends signals to employees about a firm's norms, values, business standards, and working environment (Greening $\&$ Turban, 1996). If job seekers value and appreciate the company having decent norms, values, and standards, their JPI towards a specific company is likely boosted. Moreover, if the organization is more engaged in CSR initiatives, the job seeker's perspectives about the organization's image is more likely to be improved and enhance JPI of job seekers.

\subsection{Job Pursuit Intention}

According to Aiman-Smith et al. (2001), JPI is defined as the willingness of job seekers to find more information about an organization, keep in touch with the firm and regard the company as a great place to work. Jaidi et al. (2011) indicate that JPI is an applicant's intention to pursue a job opportunity and attend a job interview at a specific company. However, Beenen and Pichler (2014) define JPI from a different perspective. JPI is the intentions, behaviors, or decision of potential employees to become a member of a particular organization.

Although the definition of JPI is defined inconsistently, this study utilizes the concept of Highhouse et al. (2003) where JPI is defined as the candidate's intention to pursue job opportunities at a specific company. The significant relationship between CSR and JPI has been found in many empirical studies (Catano \& Morrow Hines, 2016; Chaudhary, 2018; Kumari \& Saini, 2018; Moorthy et al., 2017; Tsai et al., 2014). In this study, the effects of each dimension of corporate social performance (i.e., economic, legal, ethical, and philanthropic citizenship) are investigated to better understand how each dimension affects JPI, which assists the organization in tailoring recruitment strategy more effectively and efficiently. All in all, the interaction effect of each dimension in association with JPI is examined in more detail in the following sectors.

\subsection{Economic Citizenship}

Lin et al. (2012) define economic citizenship as an employer's responsibility to provide its employees' benefits such as training and education, job safety, good working environment, and salary while remaining or improving its 
profitability through supplying goods or services (Cable \& Judge 1994; Weyzig 2009). General findings from the recruitment literature indicate that the perceived economic citizenship positively influences the job seekers' JPI (Lin et al., 2012; Maurice, 2019; Moorthy et al., 2017; Prihatiningsih et al., 2017; Tsai et al., 2014). Lin et al. (2012) and Maurice (2019) indicate that economic citizenship is the most powerful factor affecting firms' attractiveness. Consistent with the results of Lin et al. (2012), Tsai et al. (2014) also claim that the positive significant effect of economic citizenship on JPI suggests an approach to attract potential job seekers. They add on that JPI of job seekers is unlikely to increase if they perceive poor economic citizenship. Therefore, Moorthy et al. (2017) promulgate that management should always keep polishing economic citizenship by providing up-to-date training, enhanced working environment, job safety, etc., to its employees. Based on these findings, this proposed hypothesis is tested:

H1. Economic responsibility positively influences prospective employee's JPI.

\subsection{Legal Citizenship}

Legal citizenship is defined as the organization's responsibilities to complete its mission under the requirements of legal and law framework (Lin et al., 2012). According to Caron et al. (2020), legal incentives appear to be essential for Canadian mining employers to recruit indigenous employees. Similar results are also found in the research of Maurice (2019) when examining the perceptions of millennials (born between 1981 - 1996) about the attractiveness of the German company's CSR Communication. The data analysis reveals that legal responsibility is the most influential factor that respondents claim to be vital to perceive employers as attractive.

Lin et al. (2012) indicate that firms' attractiveness is directly influenced by legal citizenship. Managers are suggested to promote business codes complying with laws, rules, and regulations to clarify any confusion in the hiring process. Managers must be determined to eliminate unlawful opportunistic behaviors that destroy the organization's legitimacy as such behaviors cause a lack of confidence among prospective employees and decrease employer attractiveness. The same findings are shown in the other studies (Moorthy et al., 2017; Prihatiningsih et al., 2017; Tsai et al., 2014). Thus, the following hypothesis is proposed:

H2. Legal responsibility positively influences prospective employee's JPI.

\subsection{Ethical Citizenship}

According to Lin (2010), ethical citizenship refers to the organization's practices that are expected or requested by its society to protect the moral rights of stakeholders although they are not codified into law such as fairness toward business partners and co-workers, freedom to report any misconduct at work, comprehensive code of conduct in ethics. Ethical citizenship is regarded as the moral and ethical responsibility of not only every business, but also every human beings. In behaving according to moral standards and in line with their values, organizations could brand themselves as ethical employers to attract job seekers (Jonsen et al., 2019). Based on signaling theory, ethically-branded companies send out market signals through ethical certifications or word-ofmouth to increase organizational attractiveness (Osburg et al., 2020).

Going beyond a company's obligation to abide by the framework of legal requirements, a corporate ethical policy can increase JPI (Katsanou, 2020; Maurice, 2019; Samuel \& Mazingi, 2019). Likewise, Samuel and Mazingi (2019) confirm the positive association between the applicant's perceived ethical responsibility of a company and their attraction to the company. Applicants are hesitant to join a company that is notorious for unethical and immoral behaviors such as unethical and unfair labor relation practices, sexual or racial discriminatory employment policy, environmental pollution, and the other concerning ethical violations. Katsanou (2019) affirms that the company's operation driven by ethical practices is more likely to attract a high-caliber workforce. The employees would like to work for a company that makes investments to build a better life for younger generations and also care about the prosperity of future generations. The positive effects of ethical responsibility on attracting job seekers are also identified in prior studies (Chaudhary, 2018; Duarte et al., 2014; Story et al., 2016). Based on the results of these studies, the proposed hypothesis is as follows:

H3. Ethical responsibility positively influences prospective employee's JPI.

\subsection{Philanthropic citizenship}

Philanthropic citizenship refers to the organization's responsibility to be engaged in social activities that are not required or mandated by laws or the company's codes of conduct (Lin et al., 2012). Philanthropic citizenship involves different forms such as donating services, goods, or funds to other organizations, communities or simply encouraging volunteer activities among customers and employees through different types of collaborations (Tsai et al., 2014). Prior studies conducted by Moorthy et al. (2017), Prihatiningsih et al. (2017); Tsai et al. (2014) assert that philanthropic responsibility has a big influence on the JPI of job seekers. Frick (2018) also find that philanthropic CSR influences JPI positively. From this, he suggests that organizations 
should consider presenting philanthropic activities in the job listing statements. Although this listing can be lengthy, it conveys values that can potentially benefit organization in recruitment. Thus, the following hypothesis is proposed:

H4. Philanthropic responsibility positively influences the applicants'JPI.

\subsection{Research Model}

Resulting from the above analysis, a research model is proposed with four dimensions of CSR, namely, economic citizenship, legal citizenship, ethical citizenship, philanthropic citizenship, and one dependent factor as JPI. Figure 1 shows the model:

\section{Research Methodology}

The study uses secondary data and primary data with qualitative and quantitative research methods. As for the secondary data, books, published journals and other sources such as websites, businesses' reports, etc., together with content analysis of signaling theory have been used to explain the relationship between CSR and JPI of potential employees in the logistics industry in Vietnam.

And for the primary data, some techniques and tools are completed under the qualitative and quantitative modes. Firstly, the authors organized consultations with 10 experts, including researchers and human resources managers, and five in-depth structured interviews with 30 randomlyselected employees for the exploration of the hidden factors, research problems, research objectives, and measurement scales. Furthermore, a pilot test has been carried out with 30 randomly-selected employees working in logistics companies in Vietnam to highlight misunderstandings, grammar, and quality of the questionnaire. As a result, some amendments and adjustments have been made to finalize the questionnaire with more appropriate words, question changes, and a more logical order in the questions. The final questionnaire includes 16 items multidimensions scale of CSR adapted from the study of Lin (2010) and JPI scale with four items from Highhouse et al. (2003). Regarding sample size, a total of 300 self-administered questionnaires were distributed to employees working in the logistics companies in Vietnam. Consequently, the number of valid and complete responses is 288. The sampling technique is the convenience technique. Then, the data is processed with statistical techniques, such as Cronbach's Alpha, Exploratory Factor Analysis (EFA), and regression analysis for answering research questions.

\section{Findings and Discussion}

\subsection{Findings}

Table 1: Demographic analysis

\begin{tabular}{|l|c|c|}
\hline Items & Amounts & Ratio \\
\hline Gender & & \\
\hline Female & 120 & $41.67 \%$ \\
\hline Male & 168 & $58.33 \%$ \\
\hline Total & 288 & $100 \%$ \\
\hline Age & & \\
\hline$\leq 21$ & 30 & $9.93 \%$ \\
\hline $22-25$ & 56 & $18.54 \%$ \\
\hline $25-28$ & 112 & $37.09 \%$ \\
\hline$\geq 28$ & 104 & $34.44 \%$ \\
\hline Total & 288 & $100 \%$ \\
\hline
\end{tabular}

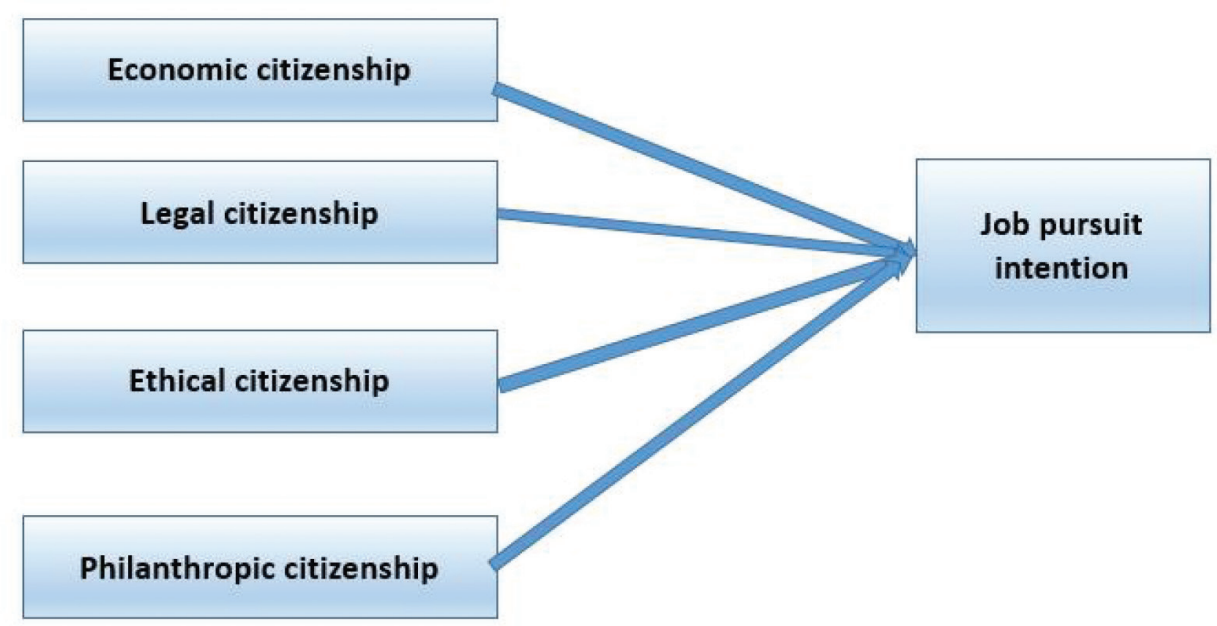

Figure 1: The research model 
Table 2: Cronbach's Alpha coefficients of the scales

\begin{tabular}{|c|c|c|c|c|}
\hline Items & $\begin{array}{c}\text { Scale Mean if Item } \\
\text { Deleted }\end{array}$ & $\begin{array}{c}\text { Scale Variance if Item } \\
\text { Deleted }\end{array}$ & $\begin{array}{l}\text { Corrected Item- Total } \\
\text { Correlation }\end{array}$ & $\begin{array}{c}\text { Cronbach's Alpha if Item } \\
\text { Deleted }\end{array}$ \\
\hline \multicolumn{4}{|c|}{ Economic Citizenship (EC) } & Cronbach's Alpha $=0.881$ \\
\hline EC1 & 10.46 & 5.699 & 0.647 & 0.890 \\
\hline EC2 & 10.39 & 6.112 & 0.652 & 0.882 \\
\hline EC3 & 10.33 & 5.545 & 0.850 & 0.808 \\
\hline EC4 & 10.33 & 5.545 & 0.850 & 0.808 \\
\hline \multicolumn{4}{|c|}{ Legal Citizenship (LC) } & Cronbach's Alpha $=0.776$ \\
\hline LC1 & 8.02 & 5.258 & 0.409 & 0.819 \\
\hline LC2 & 8.68 & 5.020 & 0.634 & 0.718 \\
\hline LC3 & 8.38 & 3.805 & 0.723 & 0.656 \\
\hline LC4 & 8.43 & 4.532 & 0.636 & 0.707 \\
\hline \multicolumn{4}{|c|}{ Ethical Citizenship (ET) } & Cronbach's Alpha $=0.855$ \\
\hline ET1 & 10.50 & 7.798 & 0.483 & 0.895 \\
\hline ET2 & 10.72 & 6.222 & 0.822 & 0.764 \\
\hline ET3 & 10.68 & 5.557 & 0.863 & 0.738 \\
\hline ET4 & 10.39 & 6.628 & 0.650 & 0.836 \\
\hline \multicolumn{4}{|c|}{ Philanthropic citizenship (PC) } & Cronbach's Alpha $=0.847$ \\
\hline PC1 & 11.10 & 5.950 & 0.641 & 0.824 \\
\hline $\mathrm{PC2}$ & 11.19 & 6.209 & 0.645 & 0.823 \\
\hline PC3 & 11.32 & 5.549 & 0.704 & 0.797 \\
\hline PC4 & 11.32 & 5.482 & 0.751 & 0.776 \\
\hline \multicolumn{4}{|c|}{ Job pursuit intention (JPI) } & Cronbach's Alpha $=\mathbf{0 . 8 4 3}$ \\
\hline JPI1 & 11.07 & 5.953 & 0.634 & 0.820 \\
\hline $\mathrm{JPI} 2$ & 11.18 & 6.135 & 0.645 & 0.816 \\
\hline $\mathrm{JPI} 3$ & 11.30 & 5.550 & 0.693 & 0.795 \\
\hline $\mathrm{JPI} 4$ & 11.30 & 5.438 & 0.745 & 0.771 \\
\hline
\end{tabular}

The reliability of instruments was checked by computing the Cronbach's Alpha coefficient and corrected item-total correlation. Cronbach's Alpha reliability coefficient normally ranges between 0 and 1. The closer Cronbach's Alpha coefficient is to 1.0 , the greater the internal consistency of the items in the scale (Gliem \& Gliem, 2003). In this study, Cronbach's Alpha coefficient for all factors was above 0.6, indicating satisfactory internal consistency of the items in the scale. Also, the item-total correlation of all items was over 0.3 , which indicates that the corresponding items correlate very well with the scale overall. Based on these two tests, the factor analysis was considered to be appropriate for the measurement scale.

Many authors propose the retention of variables with a factor loading above 0.5 for further analysis (Jayawardhena, 2004). A factor analysis was performed on the 20 survey items. Consequently, all items had a factor loading more than 0.5. Therefore, the dimensions were named economic citizenship, legal citizenship, ethical citizenship, philanthropic citizenship, and JPI.

The correlation analysis shows the significant positive effects of economic citizenship, legal citizenship, ethical citizenship on JPI $(p<0.05)$. However, there is no significant relationship between philanthropic citizenship and JPI. Subsequently, a regression analysis is performed to determine which independent variables have the most effect on a dependent variable.

The result shows that economic citizenship, legal citizenship, and ethical citizenship are positively related to the JPI of existing employees. However, economic citizenship is the most powerful factor with $\beta=0.52$, followed by legal citizenship $(\beta=0.211)$ and ethical citizenship $(\beta=0.203)$. The data analysis shows there is no relationship between philanthropic citizenship and JPI. 
Table 3: Correlations

\begin{tabular}{|c|c|c|c|c|c|c|}
\hline & & $\mathbf{M}$ & MeanCA & MeanWLB & MeanCSR & MeanJPI \\
\hline \multirow{3}{*}{ EC } & Pearson Correlation & 1 & .223 & .366 & -.008 & .691 \\
\hline & Sig. (2-tailed) & & .000 & .000 & .888 & .000 \\
\hline & $\mathrm{N}$ & 288 & 288 & 288 & 288 & 288 \\
\hline \multirow{3}{*}{ LC } & Pearson Correlation & .223 & 1 & .159 & .000 & .364 \\
\hline & Sig. (2-tailed) & .000 & & .007 & .997 & .000 \\
\hline & $\mathrm{N}$ & 288 & 288 & 288 & 288 & 288 \\
\hline \multirow{3}{*}{ ET } & Pearson Correlation & .366 & .159 & 1 & -.106 & .464 \\
\hline & Sig. (2-tailed) & .000 & .007 & & .073 & .000 \\
\hline & $\mathrm{N}$ & 288 & 288 & 288 & 288 & 288 \\
\hline \multirow{3}{*}{ PC } & Pearson Correlation & -.008 & .000 & -.106 & 1 & .031 \\
\hline & Sig. (2-tailed) & .888 & .997 & .073 & & .604 \\
\hline & $\mathrm{N}$ & 288 & 288 & 288 & 288 & 288 \\
\hline \multirow{3}{*}{ JPI } & Pearson Correlation & .691 & .364 & .464 & .031 & 1 \\
\hline & Sig. (2-tailed) & .000 & .000 & .000 & .604 & \\
\hline & $\mathrm{N}$ & 288 & 288 & 288 & 288 & 288 \\
\hline
\end{tabular}

Table 4: Model Summary

\begin{tabular}{|l|c|c|c|c|c|}
\hline Model & $\mathbf{R}$ & $\mathbf{R}$ Square & Adjusted R Square & Std. Error of the Estimate & Durbin-Watson \\
\hline 1 & $.756^{\mathrm{a}}$ & .571 & .565 & .47813 & 2.069 \\
\hline
\end{tabular}

Table 5: Regression results of the model

\begin{tabular}{|c|c|c|c|c|c|c|c|c|}
\hline \multicolumn{9}{|c|}{ Coefficients } \\
\hline \multirow{2}{*}{\multicolumn{2}{|c|}{ Model }} & \multicolumn{2}{|c|}{ Unstandardized Coefficients } & \multirow{2}{*}{$\begin{array}{c}\text { Standardized Coefficients } \\
\text { Beta }\end{array}$} & \multirow[t]{2}{*}{$\mathbf{t}$} & \multirow[t]{2}{*}{ Sig. } & \multicolumn{2}{|c|}{ Collinearity Statistics } \\
\hline & & B & Std. Error & & & & Tolerance & VIF \\
\hline \multirow{5}{*}{1} & (Constant) & .275 & .224 & & 1.225 & .222 & & \\
\hline & $\mathrm{EC}$ & .520 & .039 & .561 & 13.185 & .000 & .838 & 1.194 \\
\hline & LC & .211 & .042 & .202 & 5.037 & .000 & .943 & 1.060 \\
\hline & ET & .203 & .037 & .233 & 5.511 & .000 & .849 & 1.177 \\
\hline & $\mathrm{PC}$ & .056 & .036 & .060 & 1.531 & .127 & .988 & 1.013 \\
\hline
\end{tabular}

Finally, the linear regression equation is as follows: JPI = $0.520 * \mathrm{EC}+0.211 * \mathrm{LC}+0.203 * \mathrm{ET}$

On the other hand, the regression equation was not autocorrelated.

\subsection{Discussion}

This is a pioneer study is a pioneer that examines how different dimensions of CSR generate direct effects on the JPI of employees. This study is a vital complementary research for previous literature by empirically clarifying such direct effects of CSR's each dimension on JPI. As indicated, the survey results reveal that, among four dimensions of CSR, economic citizenship, which involves providing employees opportunities to develop their skills continuously, job training, good working environment, liberal wages, and benefits, appear to be the most influential factor with the largest $\beta$ coefficient at 0.536 , followed 
by legal citizenship $(\beta=0.211)$ and ethical citizenship $(\beta=0.203)$. Similarly, the role of economic citizenship has been perceived to be the most vital factor when job seekers pursue their future job in studies by Moorthy et al. (2017) and Lin et al. (2012). Economic citizenship represents the right to economic freedom and independence, the right to self-support. Contrary to the public's belief that Vietnamese women are economic dependents or family burdens, Huang (2017) points out that Vietnam is the country that has the highest female workforce participation in the world; women are the breadwinners of the family. Therefore, the provision of economic citizenship practices by employers is crucial because self-support is an obligation to every individual in any community of citizens.

A significant relationship between ethical citizenship and JPI has been found in this study. This result confirms the findings of a recent study in Brazil by Cohen et al. (2017), indicating that the social-environmental responsibility of companies has a significant impact on the attraction and retention of young professionals. In addition, Barbara et al. (2019) also affirm that prospective employees in the Algeria - a developing country - prefer to work for ethical companies. This result implies that unethical or less ethical companies have to endure additional expenses related to recruiting such as higher salaries.

In terms of legal citizenship, this study indicates a significantly positive association between legal citizenship and JPI. It is reasonably unlikely that legal or law-abiding applicants would like to work for an organization that is notorious for general and consistent breach of environmental law and labor, workplace discriminations, unfair labor practices, and labor rights abuses.

\section{Conclusions}

Based on the argument of signaling theory associated with utilizing qualitative and quantitative research approaches, this study reveals that, overall, economic citizenship, legal citizenship, and ethical citizenship are positively related to the JPI of employees in the logistics industry in Vietnam. As a result, these findings suggest that organizations in the logistics industry should communicate clear and consistent CSR practices related to economic citizenship, legal citizenship, and ethical citizenship in job advertisements to enhance the JPI of job seekers.

In terms of theoretical implications, the study helps to deepen and expand the existing literature on JPI in various contexts. It is vital to acknowledge that modern businesses recruit employees from different backgrounds such as socioeconomic status, education, age, religion, culture, and nationality. These people from diverse backgrounds again come into the workplace with different perceptions, goals, and values. Therefore, future research is essential to investigate perceptions of specific groups, and HR managers can utilize these findings to design CSR policies more purposely and effectively.

In terms of practical implications, these findings suggest that organizations operating in the logistics industry should strategically develop and improve firm's policies related to economic citizenship, legal citizenship, and ethical citizenship. Engagement in CSR practices results in, not only higher brand equity (Zahari et al., 2020), but also enhanced JPI of job seekers. The applicant's higher JPI provides the organization with a bigger opportunity to recruit high-quality human resources. Because economic citizenship has the greatest effect on the JPI of potential employees, companies should focus more on providing employees benefits such as training and education, development, job safety, a good working environment, and salary. Especially, in the Industrial Revolution 4.0 and innovative technologies of logistics 4.0, the provision of training and other forms of development to employees is indispensable. As a result, it helps to improve the innovative skills and learning of the workforce. In essence, the training programs do not necessarily involve employee's work directly, but can be aimed at different types of training that enables employees to perform a diversity of jobs. Given the continuous transformation of technologies, training should be identified as a constant process. Besides, salary and benefits should be based on the employee's contributions to the company. There should be a clear relationship between work performance and rewards. Regarding legal citizenship and ethical citizenship, some programs can be implemented to shape a positive image in the perceptions of employees such as more respect of the law and regulation, protecting the environment, fairness with partners and employees, etc.

This research has some limitations. Firstly, this study focuses on examining the JPI of potential employees in the logistics sector only; thus, the results cannot be generalized to other sectors. Different industries in different countries, and different backgrounds could yield different results. Therefore, it is a call for more research to identify appropriate factors for each specific context. Secondly, although much research has been carried out to test the relationship between CSR and JPI, the studies related to the moderating and mediating mechanism in this association is still very limited. Thus, further research is encouraged to fill this research gap.

\section{References}

Aiman-Smith, L., Bauer, T.N., \& Cable, D.M. (2001). Are you attracted? Do you intend to pursue? A recruiting policycapturing study. Journal of Business and Psychology, 16(2), 219-237.

Barbara, L., Grolleau, G., \& Mzoughi, N. (2019). Attracting employees in developing countries through corporate social responsibility initiatives. Strategic Change, 28(4), 255-258.

Bayraktar, O., \& Ataç, C. (2018). The effects of Industry 4.0 on Human resources management. In Peter Lang eds 
Globalization, Institutions and Socio-Economic Performance, GmbH Publisher, pp. 337-360.

Beenen, G., \& Pichler, S. (2014). Do I really want to work here? Testing a model of job pursuit for MBA interns. Human Resource Management, 53(5), 661-682.

Caron, J., Asselin, H., \& Beaudoin, J.-M. (2020). Indigenous employees' perceptions of the strategies used by mining employers to promote their recruitment, integration, and retention. Resources Policy, 68, 1-11.

Catano, V.M., \& Morrow Hines, H. (2016). The influence of corporate social responsibility, psychologically healthy workplaces, and individual values in attracting millennial job applicants. Canadian Journal of Behavioural Science, 48(2), 142-154.

Celani, A., \& Singh, P. (2011). Signaling theory and applicant attraction outcomes. Personnel Review, 40(2), 222-238.

Chaudhary, R. (2018). Can green human resource management attract young talent? An empirical analysis. Paper presented at the Evidence-based HRM: A Global Forum for Empirical Scholarship.

Cohen, M., Cavazotte, F. d. S.C.N., Costa, T.M.d., \& Ferreira, K.C.S. (2017). Corporate social-environmental responsibility as an attraction and retention factor for young professionals. BBR. Brazilian Business Review, 14(1), 21-41.

Dawkins, C.E., Jamali, D., Karam, C., Lin, L., \& Zhao, J. (2016). Corporate social responsibility and job choice intentions: A cross-cultural analysis. Business \& Society, 55(6), 854-888.

Duarte, A.P., Gomes, D., \& Neves, J. (2014). Finding the jigsaw piece for our jigsaw puzzle with corporate social responsibility: The impact of CSR on prospective applicants' responses. Management Research: The Journal of the Iberoamerican Academy of Management, 3, 240-258.

Ehrhart, K.H., \& Ziegert, J.C. (2005). Why are individuals attracted to organizations? Journal of Management, 31(6), 901-919.

Frick, J.A. (2018). The Effects of External Philanthropic CSR on Job Seekers' Perceptions. Saint Leo University.

Gliem J.A., \& Gliem, R.R. (2003) Calculating, interpreting, and reporting Cronbach's Alpha reliability coefficient for LikertType Scales. Midwest Research to Practice Conference in Adult, Continuing, and Community Education, Columbus, 82-88.

Greening, D.W., \& Turban, D.B. (1996). Corporate Social Performance and Organizational Attractiveness to Prospective Employees. The Academy of Management Journal, 40(3), 658672.

Greening, D.W., \& Turban, D.B. (2000). Corporate social performance as a competitive advantage in attracting a quality workforce. Business \& Society, 39(3), 254-280.

Hetze, K. (2016). Effects on the (CSR) reputation: CSR reporting discussed in the light of signalling and stakeholder perception theories. Corporate Reputation Review, 19(3), 281-296.
Highhouse, S., Lievens, F., \& Sinar, E. F. (2003). Measuring attraction to organizations. Educational and Psychological Measurement, 63(6), 986-1001.

Huang, P. (2017). Dependent or breadwinner? Vietnamese brides reshaping gender roles at the China-Vietnam border. The Journal of Chinese Sociology, 4(1), 1-17.

Jaidi, Y., Van Hooft, E. A., \& Arends, L. R. (2011). Recruiting highly educated graduates: A study on the relationship between recruitment information sources, the theory of planned behavior, and actual job pursuit. Human Performance, 24(2), 135-157.

Jayawardhena, C. (2004). Measurement of service quality in internet banking: the development of an instrument. Journal of marketing management, 20(1-2), 185-207.

Jonsen, K., Point, S., Kelan, E.K., \& Grieble, A. (2019). Diversity and inclusion branding: a five-country comparison of corporate websites. The International Journal of Human Resource Management, 1, 1-34.

Katsanou, S., (2019). Corporate Social Responsibility as a recruitment strategy; Attracting human workforce through the creation of an ethical profile and ethical practices. Master's thesis. International Hellenic University, Greece.

Kumari, S., \& Saini, G. K. (2018). Do instrumental and symbolic factors interact in influencing employer attractiveness and job pursuit intention? Career Development International, 23(4), 444-462.

Le, Q.T.T., Doan, T.H.D., Nguyen, Q.L.H.T.T., \& Nguyen, D.T.P. (2020). Competency Gap in the Labor Market: Evidence from Vietnam. Journal of Asian Finance, Economics and Business, 7(9), 697-706. https://doi.org/10.13106/jafeb.2020.vol7. no9.697

Lin, C.-P. (2010). Modeling corporate citizenship, organizational trust, and work engagement based on attachment theory. Journal of Business Ethics, 94(4), 517-531.

Lin, C.-P., Tsai, Y.-H., Joe, S.-W., \& Chiu, C.-K. (2012). Modeling the relationship among perceived corporate citizenship, firms' attractiveness, and career success expectation. Journal of Business Ethics, 105(1), 83-93.

Linh, M.N.P \& Huong, T.T.N. (2020). The Supply Chain and Logistics of Vietnam in the context of international economic integration. International Business Research, 13(7), 27-44.

Maurice, E. C. (2019). CSR Communication and its influence on employer attractiveness: Do millennials swipe right for German companie's CSR Communication? Master's thesis. UPF Barcelona School of Management.

My, T.T.T (2020). Enhancing Corporate Social Responsibility in Vietnam for sustainable development. Retrieved from http:// tapchicongthuong.vn/bai-viet/nang-cao-trach-nhiem-xa-hoicua-doanh-nghiep-o-viet-nam-nham-muc-tieu-phat-trien-benvung-72855.htm

Moorthy, K., Na, S. A., Yee, C. W., Xian, C. Y., Jin, O. T., Mun, T. S., \& Shan, W. S. (2017). Influence of corporate social responsibility in job pursuit intention among prospective 
employees in Malaysia. International Journal of Law and Management, 59(6), 1159-1180.

Nguyen, X.T., \& Luu, Q.K. (2020). Factors Affecting Adoption of Industry 4.0 by Small-and Medium-Sized Enterprises: A Case in Ho Chi Minh City, Vietnam. Journal of Asian Finance, Economics and Business, 7(6), 255-264. https://doi. org/10.13106/jafeb.2020.vol7.no6.255

Nguyen, H.P. (2020). Human resource management of logistics in Vietnam: Status and policy solutions. Human Resource Management, 11(3), 569-583.

Osburg, V.-S., Yoganathan, V., Bartikowski, B., Liu, H., \& Strack, M. (2020). Effects of ethical certification and ethical eWoM on talent attraction. Journal of Business Ethics, 164(3), 535-548.

Prihatiningsih, W., Syaebani, M. I., \& Devina, M. (2017). Impact Analysis On Corporate Social Responsibility Towards Job Pursuit Intention With Socio-Environmental Consciousness As A Moderating Variable: Case Study Of Undergraduate Students At Universitas Benefit. Benefit: Jurnal Manajemen dan Bisnis, 2(2), 115-124.

Rodríguez-Espíndola, O., Albores, P., \& Brewster, C. (2018). Disaster preparedness in humanitarian logistics: A collaborative approach for resource management in floods. European Journal of Operational Research, 264(3), 978-993.

Samuel, O. M., \& Mazingi, A. (2019). Exploring dimensions of corporate social performance as a strategy for attracting quality job seekers. Southern African Business Review, 23(1).

Story, J., Castanheira, F., \& Hartig, S. (2016). Corporate social responsibility and organizational attractiveness: implications for talent management. Social Responsibility Journal, 12(3), 485-504.

Syaebani, M. I., Anoviar, A. N., Pusparini, E. S., \& Rachmawati, R. (2015). Explaining Factors of Job Pursuit Intention in Indonesian Military Institution. Asia Pacific Management and Business Application, 3(3), 171-181.

Thu, T.N. (2020). Promoting the cooperation in educating and training the high-end human resources in Logistic industry. Retrieved from http://tapchitaichinh.vn/tai-chinh-kinh-doanh/ thuc-day-hop-tac-dao-tao-nguon-nhan-luc-chat-luong-caonganh-logistic-328370.html

Tsai, Y.-H., Joe, S.-W., Lin, C.-P., \& Wang, R.-T. (2014). Modeling job pursuit intention: Moderating mechanisms of socioenvironmental consciousness. Journal of Business Ethics, 125(2), 287-298.

Turban, D.B., \& Cable, D.M. (2003). Firm reputation and applicant pool characteristics. Journal of Organizational Behavior: The International Journal of Industrial, Occupational and Organizational Psychology and Behavior, 24(6), 733-751.

Williamson, I.O., Lepak, D.P., \& King, J. (2003). The effect of company recruitment web site orientation on individuals' perceptions of organizational attractiveness. Journal of Vocational Behavior, 63(2), 242-263.

Zahari, A. R., Esa, E., Rajadurai, J., Azizan, N.A., \& Muhamad Tamyez, P.F. (2020). The Effect of Corporate Social Responsibility Practices on Brand Equity: An Examination of Malaysia's Top 100 Brands. Journal of Asian Finance, Economics, and Business, 7(2), 271-280. https://doi. org/10.13106/jafeb.2020.vol7.no2.271 